\title{
Gender Differences in Learning Burnout among Special Education Students
}

\author{
Florence Ijeoma Arumede ${ }^{1}$, Michael Eskay ${ }^{1}$, Annastasia Uchenna Eneh ${ }^{1} \&$ Jane Ogoma Aja ${ }^{1}$ \\ ${ }^{1}$ Department of Educational Foundations, University of Nigeria, Nsukka, Enugu state, Nigeria \\ Correspondence: Michael Eskay, Department of Educational Foundations, University of Nigeria, Nsukka, Nigeria. \\ E-mail: michael.eskay@unn.edu.ng
}

Received: October 27, 2019 Accepted: December 2, 2019 Online Published: December 12, 2019

doi:10.5539/gjhs.v11n14p119 URL: https://doi.org/10.5539/gjhs.v11n14p119

\begin{abstract}
This study examined gender differences in learning burnout among special education students. A research question and a null hypothesis were formulated to guide the research. A descriptive survey was employed. The study sample consisted of 700 special education students. Academic Burnout Questionnaire (ABQ) was employed for data collection. The research data were analyzed using mean, standard deviation and t-test. The finding of the study revealed that there is no significant difference between the mean ratings of male and female special education students in learning burnout. Government at all level within the study area and beyond are urged to make conducive learning environment for University students including those in special education departments.
\end{abstract}

Keywords: special education students, gender, learning burnout

\section{Introduction}

The relevance of special education made the Federal Ministry of Education (2013) to set up a plan to develop a special education and disability plan in Nigeria. Onwuegbu (1977) opined that the neglect of special education and backwardness of the discipline in Nigeria stems from the fact that many Nigerians are ignorance of the relevance of the discipline, and maintain superstition about the challenged persons among others. Caulcrick (1980) revealed that cultural belief denied challenged persons full access to formal education in the past. Obiakor (1998) asserted that misconception of the discipline affected the self-worth, placement, evaluation and instruction of special need students. Eskay (2001) maintained that the wrong perception of people with disabilities is one of the factors hindering the progress of the discipline.

Muuya (2002) believed that the major challenge of studying special education is because many individuals underrate the discipline with the notion that it is irrelevant for educating persons with disability. Akon (1991) revealed that the lack of adequate training and retraining of education teachers has posed significant challenges to the education of special need learners. Eskay (2001) reported that cultural misconception, interpretation or knowledge about special education has left teachers of the profession handicapped as some of them left the profession for unskilled persons to the detriment of her learners. The author further stated that unskilled teachers of special need children may find it difficult to identify different needs of individuals making learning uninterested for learners.

Academic advancement among students occurs at different stages ranging from nursery to postgraduate studies. In light of this academic movement, people make different career choices. According to Stallman (2010), at the university stage, the individual is preoccupied with the thoughts to attain higher in life. Stallman further noted that the student's academic stage determines the level of burnout, as students at higher institutions are faced with many academic tasks. Hamaideh (2011) acknowledged the commonness of burnout among university students. To this end, it seems like special education students in Nigeria are also affected by burnout. Carlotto and Camara (2006) added that students' burnout comprises of psychological tiredness and disengagement. Ezeudu et al. (2019) suggested that burnout among students need serious intervention. Their report may not only be important to chemistry students but also special education students. The issue of burnout could be more reflective among special education students in South-East Nigeria. Due to the dearth of evidence regarding this, it appears also that special education students are not being assisted to eliminate burnout. The purpose of this study was to ascertain gender differences in learning burnout among special education students in South-East Nigeria. 


\subsection{Research Question}

The following research questions were raised to guide the study:

What is the mean burnout of male and female special education students in South-East Nigeria?

\subsection{Hypothesis}

The hypothesis below was raised and tested at 0.05 probability level.

There is no significant difference between the mean ratings of male and female special education students in learning burnout.

\section{Research Method}

The study adopted a descriptive research design. The study covered both federal and state universities in South-East Nigeria. Academic Burnout Questionnaire (ABQ) was used to gather data for the study. The questionnaire was face-validated and the reliability established via Cronbach alpha (0.88). The instrument was administered directly to the respondents by the researchers along with two research assistants. Mean and standard deviation was used in answering the research question while t-test was used to test the hypothesis.

\section{Results}

Research Question: What is the mean burnout of male and female special education students in South-East Nigeria?

Table 1. Mean difference in learning burnout among male and female special education students

\begin{tabular}{llccc}
\hline Burnoutdimension Gender & & N & Mean & Std.Deviation \\
\hline Depersonalization & Male & 347 & 3.00 & 0.39 \\
& Female & 353 & 3.01 & 0.37 \\
Exhaustion & Male & 347 & 2.64 & 0.36 \\
& Female & 353 & 2.65 & 0.35 \\
\hline
\end{tabular}

Result in Table 1 showed that male special education students had mean depersonalization of 3.00 with standard deviation of 0.39 while female special education students had mean depersonalization of 3.01 with standard deviation of 0.37 . For mean exhaustion burnout, male special education students had 2.64 with standard deviation of 0.36 while female special education students had 2.65 with standard deviation of 0.35 .

Hypothesis: There is no significant difference between the mean ratings of male and female special education students in learning burnout.

Table 2. Independent samples t-test of significant mean difference in learning burnout

\begin{tabular}{cccccccc}
\hline Gender & $\mathbf{N}$ & $\mathbf{M} \pm$ SD & $\mathbf{t}$ & $\mathbf{d f}$ & Sig. & mean difference & 95\%CI \\
\hline Male & 347 & $2.82 \pm 0.38$ & & & & & \\
Female & 353 & $2.83 \pm 0.36$ & .243 & 698 & 0.808 & .00694 & $-.063, .049$ \\
\hline
\end{tabular}

$\mathrm{M} \pm \mathrm{SD}=$ Mean and Standard Deviation; $\mathrm{N}=$ Number of Respondents, $\mathrm{CI}=$ Confidence Interval.

Result in Table 2 showed that there is no significant difference between the mean ratings of male and female special education students in learning burnout, $t(698)=.243$, $\mathrm{p}=0.11,95 \% \mathrm{CI}=-.063, .049$.

\section{Discussion}

The study examined gender differences in burnout among special education students in South-East Nigeria. The results showed that there is no significant difference between the mean ratings of male and female special education students in learning burnout. On the contrary, Weckwerth and Flynn (2006) reported that female undergraduate students are more affected by academic burnout than male students. Weckwerth and Flynn (2006) reported that male undergraduate students score higher than female students' depersonalization burnout while female students scored lower on personal accomplishment than male counterparts. 
Furthermore, Cazan and Nastasa (2015) revealed that academic burnout is common among students of tertiary institution. Ogbueghu et al. (2019) revealed that burnout is common among undergraduate students of Economics Education. Ezeudu, et al. (2019) reported that academic burnout is common among undergraduate students of Chemistry Education. Nowack and Hanson (2003), and McCarthy, Pretty and Catano (2006) revealed that burnout poorly forecasts academic achievement of higher institution students. Stewart, Lam, Betson, Wong, and Wong (1999) revealed that the resultant effect of academic task irrespective of one's education is burnout. Adekola (2012) also found that there is no academic burnout gender variation among learners. However, Winga, Agak, and Ayere (2016) revealed that school burnout is common amongst undergraduate students. The scholars further reported that male undergraduate students' achievement score may vary considerably when compared with the female counterpart. Nwefuru et al. (2018) also reported that there is the existence of burnout among undergraduate students of South-East, Nigeria.

Charkhabi, Abarghuei, and Hayati (2013) reported that students' self-worth stimulates their academic burnout. Wu (2010) reported that students suffer from academic burnout because of academic workload, lack of academic motivation and failure to take school instructions among others. Anvari, Kalali, and Gholipour (2011) revealed that burnout is as a result of the personality features of students. Bakker, Van Der Zee, Lewig, and Dollard (2006) reported that behaviour and personality traits of students are the causes of burnout.

\section{Conclusion}

The finding shows that there is no significant difference between the mean ratings of male and female special education students in learning burnout. The study, therefore, suggests that the government of the study area and beyond should work more in creating enabling environment to improve teaching and learning of special education. There is a need also for the government to employ qualified teachers who will professionally impact the life of special education students with little or no academic stress.

\section{References}

Adekola, B. (2012). Work burnout experience among university non-teaching staff: A gender approach. International Journal of Academic Research in Business and Social Sciences, 2(1), 128-135.

Akon, E. O. (1991). In-service teacher education in Nigeria: A case study. Journal of Education for Teaching, 17(2), 189-199. https://doi.org/10.1080/0260747910170207

Anvari, M. R., Kalali, N. S., \& Gholipour, A. (2011, April). How does personality affect on job burnout? International Journal of Trade, Economics and Finance, 2(2), 115-119. https://doi.org/10.7763/IJTEF.2011.V2.88

Bakker, A. B., Van Der Zee, K. I., Lewig, K. A., \& Dollard, M. F. (2006). The relationship between the Big Five Personality Factors and burnout: A study among volunteer counselors. The Journal of Social Psychology, 146(1), 31-50. https://doi.org/10.3200/SOCP.146.1.31-50

Carlotto, M. S., \& Camara, S. G. (2006). Característicaspsicometricas do Maslach Burnout Inventory Student Survey (MBI-SS) emestudantes universitár-ios brasileiros. Psico USF, 11(2), 167-173. https://doi.org/10.1590/S1413-82712006000200005

Caulcrick, E. O. (1980). Handicapped children: Early detection, intervention and education: Selected case studies. Paris, France: UNESCO.

Cazan, A. M., \& Nastasa, L. E. (2015). Emotional intelligence, satisfaction with life and burnout among university

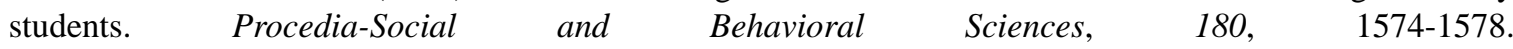
https://doi.org/10.1016/j.sbspro.2015.02.309

Charkhabi, M., Abarghuei, M. A., \& Hayati, D. (2013). The association of academic burnout with self-efficacy and quality of learning experience among Iranian students. Springer Plus, 2, 677. https://doi.org/10.1186/2193-1801-2-677

Eskay, M. (2001). Cultural perceptions of special education administrators in Nigeria. (Unpublished Doctoral Dissertation, Loyola University of Chicago, Chicago, IL.)

Ezeudu, F.O., Nwoji, I. H. N., Dave-Ugwu, P. O., Abaeme, D. O., Ikegbunna, N. R., Agugu, C. V., Muoneke, M. N., Alabi, A. O., \& Nwefuru, B. C. (2019). Intervention for Burnout among Chemistry Education Undergraduates in Nigeria. Journal of International Medical Research. https://doi.org/10.1177/0300060519867832

Federal Ministry of Education. (2013). Universal Basic Education. Abuja, Nigeria: Federal Government Press. 
Hamaideh, S. H. (2011). Stressors and reactions to stressors among university students. Int J Soc Psychiatry, 57(1), 69-80. https://doi.org/10.1177/0020764009348442

Muuya, J. (2002). Aim of special education. European Journal of Special Needs Education, 17(3), 229-239. https://doi.org/10.1080/08856250210162130

Nowack, K., \& Hanson, A. (2003). The relationship between stress, job performance, and burnout in college student resident assistants. Journal of College Student Personnel, 24, 545-550.

Nwefuru, B. C., Otu, M. S., Eseadi, C., Usen, S. A., \& Otu, F. M. (2018). Stress, Depression, Burnout and Anxiety among Chemistry Education Students in Universities in South-East, Nigeria. Journal of Consultancy, Training \& Services, 2(2), 46-54.

Obiakor, F. E. (1998). Special education reform in Nigeria: Prospects and challenges. European Journal of Special Needs Education, 13(1), 57-71. https://doi.org/10.1080/0885625980130106

Ogbueghu, S. N., Aroh, P. N., Igwe, R. A., Dauda, J. E., Yahaya, J., Nwefuru, B. C., Eneogu, N. D., \& Okere, F. C. (2019). Gender differences in academic burnout among Economics Education undergraduate students in South-East, Nigeria. Global Journal of Health Science, 11(14), 46-51. https://doi.org/10.5539/gjhs.v11n14p46

Onwuegbu, O. L. (1977). The Nigerian culture: Its perceptions and treatment of learners with disabilities. Oyo, Nigeria: Federal Advanced Teachers College.

Stallman, H. M. (2010). Psychological distress in university students: A comparison with general population data. Australian Psychologist, 45(4), 249-257. https://doi.org/10.1046/j.1365-2923.1999.00294.x

Stewart, S. M., Lam, T. H., Betson, C. L., Wong, C. M., \& Wong, A. M. P. (1999). A prospective analysis of stress and academic performance in the first two years of medical school. Medical Education, 33, 243-250.

Weckwerth, A. C., \& Flyn, D. M. (2006). Effect of sex on perceived support and burnout in university students. College Student Journal, 40(2), 237-249.

Winga, M. A., Agak, J. O., \& Ayere, A. M. (2016). The relationship between school burnout, gender and academic achievement amongst secondary school students in Kisumu East sub-county, Kenya. Journal of Emerging Trends in Educational Research and Policy Studies, 7(5), 326-331.

Wu, W. (2010). Study on college students' learning burnout. Asian Social Sciences, 6(3), 132-134.

\section{Copyrights}

Copyright for this article is retained by the author(s), with first publication rights granted to the journal.

This is an open-access article distributed under the terms and conditions of the Creative Commons Attribution license (http://creativecommons.org/licenses/by/4.0/). 